\title{
Legal Aspect of the Execution of Arbitration Online Decision in Domain Name Dispute
}

\author{
Hetty Hassanah \\ Faculty of Law \\ Universitas Komputer Indonesia \\ Bandung, Indonesia \\ Hetty.hassanah@email.unikom.ac.id
}

\author{
Eman Suparman \\ Faculty of Law \\ Universitas Komputer Indonesia \\ Bandung, Indonesia \\ Eman.suparman@email.unikom.ac.id
}

\begin{abstract}
Domain name is one of the software in ecommerce as cyberspace activity that border less world. Issue arising from the activity in the virtual world is often to be a legal dispute, including unauthorized use of another person of the domain name currently become a legal dispute, and the settlement can be done through the judiciary or outside the judicial institution such as Online Arbitration. The problem which researched is how the implementation of the online arbitration decision in domain name dispute as well as the legal protection that should be obtained by users of well-intentioned domain names. Effort to obtain an overview of the execution of the online arbitration in domain name dispute, a study using the normative juridical method and the data obtained were analyzed by qualitative juridical. The result of research is arbitration as a dispute resolution currently does by the Internet (online arbitration), without any real meeting between the parties to the dispute. In practice, online arbitration decision is implemented online without any legal effort, especially because the arbitration decision is the final and binding for the parties. The execution of such online arbitration decisions is often deemed not to reflect a sense of justice for the parties and ultimately undertakes other remedies, where as the arbitral award cannot be made by appeals or cassation or judicial appeals as well as re-submission of the same case. Therefore, a well-intentioned domain name user must have legal protection in using his registered domain name.
\end{abstract}

Keywords-domain name, electronic commerce, online arbitration, final and binding, Execution of arbitration decisions.

\section{INTRODUCTION}

The legal aspect of the implementation of online arbitration decisions in domain name disputes is very important to achieve legal certainty, because in Indonesia there is no specific regulation on this matter. Article 24 of the Law of Information and Electronic Transaction only states that the resolution of domain name disputes can be carried out in litigation (through a general justice institution) or non-litigation (through an alternative dispute resolution mechanism).

There have been some previous researches, among others, on the Protection of Brands from Cybersquatting Related to the Development of Information and Communication Technology and the Concept of its Arrangement in Indonesia[1]. But the study only discussed the dispute of cybersquatting, but it does not analyze the legal aspects relating to the implementation of online arbitase decisions in domain name disputes, whereas cybersquatting is a dispute over the abuse of domain names, so it is unclear how online arbitration decisions in cybersquatting disputes are carried out according to law in Indonesia, and this creates legal uncertainty in implementation of the decision. Business dispute resolution through online dispute resolution in Indonesia, in this study was only discussed the general business dispute, does not discuss the legal aspects in the implementation of online arbitration decisions, as one method of resolving business disputes electronically outside the court or non litigation[2]. Meanwhile, the implementation of this online arbitration award is still confusing because it is different from the implementation of conventional arbitration decisions in business disputes, which in turn arises the problem of pros and cons of its implementation. Furthermore, there is a study of case studies completed by the WIPO Arbitration \& Mediation Center, even this only makes the procedure of dispute resolution only, however, there is no legal analysis of the implementation of the online arbitration award which is against parties from various countries who do not have specific legal provisions, only based on terms and conditions when an agreement is made[3]. The use of information technology in resolving domain name disputes through online arbitration including how the implementation of its decisions is unavoidable because the community has now turned into an information society[4]. One way to resolve domain name disputes involving Indonesian citizens in nonlitigation is through arbitration. The emergence of domain name disputes has inspired electronic dispute resolution as well, in this case through online arbitration by Arbitration providers such as WIPO (World Intellectual Property Organization)[5]. Settlement of domain name disputes through online arbitration has its own procedural law (adjudication), as well as the implementation of its decisions. Online arbitration decisions involving Indonesian citizens are not carried out based on the equivalent of the Supreme Court such as the implementation of other arbitral awards, because it can be carried out directly by the registrant / registry as the manager of the disputed domain name, and there is no specific rule in Indonesia, resulting in uncertainty law[6] . In Indonesia there is currently no regulation specifically regulating the implementation of online arbitration decisions that are different from the implementation of conventional. arbitration decisions, thus giving rise to legal uncertainty.

My research on the legal aspects of the implementation of online arbitration decisions in domain names is currently being followed as a continuation of my previous research on Electronic Trade Dispute Resolution (E-Commerce). In previous studies only discussed about online arbitration processes in e-commerce disputes, without analyzing the legal aspects of their implementation. Thus the purpose of this study is to find legal aspects of the implementation of online arbitration decisions on domain name disputes in order to achieve legal certainty and provide legal protection for the 
parties to the dispute. The research method used is the normative juridical approach and the resulting data is analyzed qualitatively juridically. The implementation of foreign arbitration decisions in domain name disputes carried out directly by registrants /registry who manage the intended domain names, do not have to get the Supreme Court equivalent. This should be regulated in a special law regarding domain names or online arbitration. Efficiency in the implementation of online arbitration decisions is one of the goals in civil justice in Indonesia, so that it does not violate the principles in civil procedure law in general.

\section{METHOD}

The specification of the research is descriptive analytical, ie giving the facts systematically. Approach method to be used is normative juridical approach method, in this case test and review secondary data about execution of arbitration decision of domain name online dispute. All the data obtained are analyzed by qualitative juridical, in this case the analysis is done by considering the hierarchy of legislation so that the one legislation does not contradict other laws and legal certainty.

\section{RESULTS AND DISCUSSION}

The legal function of the developing Indonesian community is not sufficient in its function to ensure certainty and order, the law is expected to function more than that which can be a means of renewing the community or development facilities, including the law relating to domain name disputes[7].

Information and Communication Technology is seen as having an important function in people's lives, because the fulfillment of various needs can be done through electronic transactions, and the system is domain name[8]. In its development in the society of cyberspace users, Increasing electronic commerce volume around the world has made commercial sites as important web sites for effective promotion and advertising media. The application of domain names most often associated with the Internet is the World Wide Web (WWW), even though the internet is not synonymous with the World Wide Web, because there are still other applications such as email and so on [9]. The use of domain names is a powerful business strategy for businesses to increase revenue and grow their business, because business and trading activities can be done 24 hours a day and 7 days a week, and can be done throughout the world without any distance, time and space[10] .

Physically the domain name system (DNS) infrastructure consists of name servers, including the bottom server system that provides information that directs certain names for each Top Level Domain to the appropriate server. Internet Corporation for Assigned Names and Numbers (ICANN) is responsible for the allocation of the Top Level Domain system, and registered domain names system on a first come first served basis[11]. ICANN as an international committee that regulates the domain name policy in the world, has endorsed a method of resolving domain name disputes called UDRP (Uniform Domain Name Dispute Resolution Policy, can be accessed at hich was enacted starting on October 24, 1999. The role of ICANN is very important regarding the resolution of domain name disputes through arbitration above[12] .

The first come first served registration scheme, a party with no rights in a trademark belonging to another sometimes uses it as a domain name to sell competing product or services. More complex domain name system disputes involved parties with roughly equal claims ti dispute names, such as bussines with the same or similar trademark. It became clear that society needed new legal institution to resolve domain name dispute more effectively[13]. In response to concern about judicial remedies and the conflict between territorial trademark systems and the global dimension of the domain name disputes, ICANN approved World Intellectual Property Organization (WIPO) as a dispute reolution provider, which conducted the Uniform Dispute Resolution Policy (UDRP) for arbitration as online disputer resolution. ICANN can remedy the problem of limited applicability by improving its own image, thereby regarding power and influence over global domain name dispute resolution. Throuh these actions ICANN can craft the UDRP into a fair, efficient and consistent in international dispute resolution mechanis[14].

In Indonesia, Speaking of abuse information technology, especially domain names that cause harm to other parties, currently in Indonesia there has been an act, Undang-Undang Informasi dan Transaksi Elektronik (ITE Act). Under the Undang-Undang Informasi dan Transaksi Elektronik, the provisions on domain names are only provided for in Article 23 and Article 24 and there is no clear guidance on how to resolve the most effective domain name dispute.

Online arbitrage becomes one of the methods of resolving domain name disputes, which can be done through domain name dispute settlement institutions such as WIPO (World Intellectual Property Organization) or PANDI (Internet Domain Name Manager) and so on. WIPO is one of ICANN's accredited Arbitration Providers and has the authority to resolve domain name disputes, while PANDI is based on the Decree of the Minister of Communication and Information of the Republic of Indonesia No. BA-3443 / DJAT / MKOMINFO / 6/2007 establishing PANDI as the domain name registrar in Indonesia as well as one of the institutions authorized to resolve domain name disputes through the arbitration system, pursuant to Government Regulation No. 82 of 2012.

The arbitral award is in principle final and binding. In essence, the final means that the award of the arbitration is final or in legal language is often referred to as inkracht van gewijsde or permanent law, while binding means that the ruling is binding on all parties in an arbitration and because they must not violate the verdict. Domain name dispute resolution through online arbitration, either on WIPO or PANDI, involves odd panelists (one, three or five panels) as needed. Applicants will apply to the above institutions (WIPO or PANDI), then will be determined how many people and anyone Panel. The Panel will then review the application and evidence of UDRP violation of the use of the domain name by the Respondent. The suffixes of Panellists shall make their decision whether the disputed domain 
Name shall be transferred by the Respondent to the Applicant or not. This decision shall be directly executed by the Registry of the intended domain name.

The arbitral award in the dispute over the domain name through the Arbitration Provider (WIPO) is based on the UDRP, constituting a foreign arbitral award for the Indonesian citizen. However, in the execution of its verdict is very different from the provisions of the law on the execution of foreign arbitral award in Indonesia as regulated in Law Number 30 Year 1999 on Arbitration and Alternative Dispute Settlement (hereinafter referred to as the Law of Arbitration), which is based on the 1958 New York Convention (Indonesia accesi by Presidential Decree No. 34/1981). Under the Arbitration Law, foreign arbitral award can only be implemented in Indonesia is limited to the decision which has been registered in the Registrar of the Central Jakarta District Court and has obtained the exquality of the Chairman of the Central Jakarta District Court, in which case the foreign arbitral award is not contrary to public order. Meanwhile the online arbitration verdict through Arbitration Provider (WIPO, PANDI and so on) is directly executed through the domain name registry concerned. The online arbitration verdict in such domain name dispute may be the cancellation of the domain name or the transfer of the domain name to the winning party, so that the party declared not entitled to the domain name shall no longer be able to use the domain name, and to the decision there shall be no legal remedy or cassation, so that one party often feels aggrieved. Therefore, the parties to the dispute can still file a claim for compensation through a civil lawsuit in court, as to date there is no regulation prohibiting compensation claims in domain ownership dispute. Online arbitration domain name dispute settlement via WIPO or PANDI is only administrative, however very influential on cyber activity of the parties as a domain name user.

WIPO or PANDI by adapting UDRP has set an international footing for the use of electronic of dispute resolution system. That is made faster, effective and efficient justice redressal forum in the mode of online dispute resolution which may in the future[15]. An adequate answer to the challenging problem of cyberspace jurisdiction can neither be a simple nor a standard one. No single authority can assume sovereignty over cyberspace. The choice of any geographical cantact or any particular national will be arbitrary in cyberspace because several jurisdictions have a legitimate claim to apply theier law[16] . Alternative dispute resolution is one of dispute resolution for domain name dispute by UDRP, same as in Indonesia.

\section{CONCLUSION}

Based on the above legal analysis, it can be concluded that the Implementation of online arbitration decision in domain ownership dispute through Arbitration Provider institution such as WIPO or PANDI, executed / executed directly by registry of domain name, by transferring or not domain name to Applicant. Persons who are declared not entitled to the domain name in the above process will, of course, feel disadvantaged, therefore may file a lawsuit by court, even if the arbitral award is final and binding, but there is no prohibition to file such claim as a form of protection law to the injured party.

\section{ACKNOWLEDGMENT}

This project is financially supported by Indonesian's Ministry of Research and Technology of Directorate General of Higher Education of Doctoral Programe fund.

\section{REFERENCES}

[1] Muhamad Amirulloh, "Penggunaan Nama Kota Sebagai Nama Domain Di Indonesia,” Jurnal Sosiohumaniora, Vol 19, No 1, pp. 123, Maret 2017.

[2] Bambang Sutiyoso, "Penyelesaian Sengketa Bisnis Melalui Online dispute resolution di Indonesia," Jurnal Mimbar Hukum, Vol 20, No. 2,pp.193, Juni 2008.

[3] Elvira Lestari, "Studi Kasus Putusan WIPO Arbitration \& Mediation Centre Between Alexander Wiegard CE \& Co against Zackari Wika," Jakarta:Jurnal Hukum ,pp.72, 2015

[4] Alvin Toffler, "The Third Wave," USA:Bantam Books, pp.18, 1 Mei 1984.

[5] Paustinus Siburian, “Arbitrase On Line,” Jakarta:Djambatan, pp.9, 2004 .

[6] Ahmad M. Ramli, "Cyber Law dan HAKI Dalam Sistem Hukum Indonesia," Refika Aditama, Bandung, pp.14, 2010.

[7] Mochtar Kusumaatmadja, "Hukum, Masyarakat, dan Pembinaan Hukum Nasional,’Bandung:Binacipta, pp.13, 1995.

[8] Lawrence B. Solum, "Models of Internet Governance," Public Law Research Journal, University og Illinois,pp.120-132, 2013.

[9] Zohar Efroni, Names as Domains, "Names as Marks: Issues Concerning The Interface Between Internet Domain Names and Trademark Rights, Intellectual Property And Information Wealth: Issues And Practices In The Digital Age, Peter K. Yu, ed., Stanford's Center for Internet and Society, Praeger Publishers, pp. 56, 2007.

[10] David Baumer, J.C. Poindexter, "Cyberlaw and E-Commerce,"New York: McGraw-Hill ,pp.xviii,2002.

[11] Karl M. manheim, "An Economic Analysis on Domain Name Policy," Hastings Communications and Entertainment Law Journal, Vol. 25, Pp. 317,2014

[12] Daniel Joice, "Internet Freedom and Human Rights," European Journal of International Law, Oxford University Press, UA, pp. 155, 2015 .

[13] john G. White, “ICANN's Uniform Domain Name Dispute Resolution Policy in Action," Barkeley Technology Law Journal, Annual Review of Law and Technology, University of California Barkeley School of Law, Vol. 16, No.1, Pp. 229-249, 2001.

[14] Lisa M. Sharrock, "The Future of Domain Name Disputes Resolution : Crafting Practical International Legal Solutions From Within The UDRP Framework," Duke Law Journal, Vol. 51, No. 2, Duke University School of Law.pp. 817-849, November ,2001.

[15] C.P. Nandini and G.B. Reddy, "Resolution of Domain Name Disputes Through ADR-Impact of WIPO's Initiative Towards eUDRP, Journal of The Indian Law Institute," Vol 52, No. 1, Indian Law Institute.pp. 89-91, January-March,2010.

[16] Hatham A. Haloush, "Jurisdictional Dillema in Online Dispute : Rethinking Traditional Approaches," The International Lawyer Journal, Vol 42, No. 3, American bar Association.pp. 1129-1146, 2008 . 